\title{
Upgrading of Raw Wheat Straw Applying Fungal Treatment
}

\author{
Zaazaa Ahmed $^{1}$, Shraim Faisal ${ }^{2}{ }^{(0)}$, Abo Omar Jamal $^{1 *}$ \\ ${ }^{1}$ Department of Animal Production, Faculty of Agriculture, An-Najah National University, Nablus, P. O. Box 707, Palestine \\ ${ }^{2}$ Department of Plant Production and Protection, Faculty of Agriculture, An-Najah National University, Nablus, P. O. Box 707, Palestine \\ Email: *aboomar57@najah.edu
}

How to cite this paper: Ahmed, Z., Faisal, S. and Jamal, A.O. (2021) Upgrading of Raw Wheat Straw Applying Fungal Treatment. Open Journal of Animal Sciences, 11, 376-383. https://doi.org/10.4236/ojas.2021.113027

Received: December 19, 2020

Accepted: June 14, 2021

Published: June 17, 2021

Copyright (c) 2021 by author(s) and Scientific Research Publishing Inc. This work is licensed under the Creative Commons Attribution International License (CC BY 4.0).

http://creativecommons.org/licenses/by/4.0/

\section{(c) (i) Open Access}

\begin{abstract}
The goal of this research was to improve the nutritive value of local wheat straw (WS) through treatment with fungi Pleurotus and to determine the nutrients digestibility using Daisy ${ }^{\mathrm{II}}$ technique. Results showed that fungal treated WS had more $(\mathrm{P}<0.05)$ levels of dry matter $(\mathrm{DM})$, ash and phosphorus $(\mathrm{P})$ compared to the untreated WS. Moreover, fungal treatment had significant effect on reduction $(\mathrm{P}<0.05)$ of crude fiber, acid detergent fiber $(\mathrm{ADF})$ and neutral detergent fiber $(\mathrm{NDF})$, and resulted in significant increase $(\mathrm{P}<0.05)$ in crude protein (CP) content. Fungal treatment increased digestibility of $\mathrm{DM}, \mathrm{CP}, \mathrm{NDF}, \mathrm{ADF}$ and gross energy (GE) by $12 \%, 27 \%, 28 \%, 2 \%$ and $12 \%$, respectively. It can be concluded that fungal treatment has an advantage in upgrading raw WS.
\end{abstract}

\section{Keywords}

Wheat Straw, Fungi, Daisy ${ }^{\mathrm{II}}$ Incubator, Digestibility

\section{Introduction}

Since animal feeds are very expensive and considered as one of the most important obstacles that decrease the profitability of livestock projects in Palestine, it is urgent to try new alternatives feeds in order to reduce the problem of feed costs as possible. The high cost of feeds is one of the major obstacles facing local livestock projects. Several researches were conducted locally where some local by-products were incorporated in small ruminant rations. Results of feeding rations with by-products showed the economic feasibility of adoption of this practice. Wherever crops, crop residues and by-products are wasted, the consequences are excessive imports of feeds and environmental problems. Examples on important local crop residues and agricultural by-products are wheat straw, 
citrus pulps, tomato pulp, poultry litter and by-products of olive trees.

In Palestine, more than 34 thousand tons of soybean meal (SBM) and about 80 thousand tons of grains (corn or barley) are used in different livestock rations annually [1]. The cost of these major feed ingredients is increasing causing a big increase in production cost. It was approved by local research that a large number of local by-products (wheat straw) can be used with positive impact in livestock feeding especially when undergoing appropriate treatments [1] [2] [3].

Fungal treatment is a recent technique that could be applied to upgrade the low quality WS as ruminant feed ingredient [4] [5], however, several species of fungi were identified for this purpose [6].

The utilization of Pleurotus in treatment of wheat straw to be used as animal feed was first described by Schanel et al. [7]. The chemical composition of the roughage is keeping changes throughout the growth of the fungi. The growth of the fungi is gained through the utilization of soluble nutrients in the colonized straw [8] [9]. This process resulted in improvement in dry matter digestibility and significant reduction in lignin content. The improvement in digestibility was influenced by type of fungi [10], temperature, content of water and concentration of nutrients [11] [12], composition of the gaseous phase and substrate pretreatment [13] [14].

The objective of this research was to investigate effects of fungal treatment on WS feeding value and in vitro digestibility utilizing the Daisy ${ }^{\text {II }}$ technique.

\section{Materials and Methods}

Raw wheat straw was obtained from local source at Tulkarm city, Palestine and was transported to the faculty of agriculture farm and a portion was chopped to $1 \mathrm{~cm}$ pieces, another portion was grounded in a feed mill to be ready for later analysis.

\subsection{Treatment of Wheat Straw}

Chopped WS was soaked in tap water for $24 \mathrm{~h}$, in steel water pools of size $0.3 \times$ $0.5 \times 0.3 \mathrm{~m}$ (depth, length and width). The soaked straw was removed and packed in a steel barrel (20 liter volume) for pasteurization. Barrel contained about 2 liters of tap water at the bottom and about $2 \mathrm{~kg}$ of soaked straw. Straw was exposed for one hour to the steam generated by heating the barrel.

Wheat grain spawn of Pleurotus, was used to inoculate the straw. In the spawning room, the pasteurized straw was spread in a steel sheet and mixed with the spawn at a rate of $0.08 \mathrm{~kg}$ spawn per $2 \mathrm{~kg}$ straw (fresh weight basis) [15]. The treated straw was placed in polyethylene bag and transferred into the fermentation room where maintained at $28^{\circ} \mathrm{C}$. The relative humidity of the room was maintained at $80 \%$.

The fermentation period maintained for six weeks then bag was removed from the fermentation place for sun drying for one week.

\subsection{DaisyII In Vitro}

A filter bag technique (DaisyII; Ankom Technology Corporation, Fairport, NY, 
USA) was used for determination of dry matter and fiber fractions digestibility.

The incubator consists of four glass fermentation jars that are placed on rotation racks in the cabinet. Sample size used was $0.5 \mathrm{~g}$ per bag with 24 bags per incubation jar. Each run contained one replicate of the experimental forage samples (3 samples) as well as two standards and two blank bags. Samples were heat sealed (Heat sealer \#1915; ANKOM Technology Corporation, Fairport, NY, USA) in filter bags (Daisy ${ }^{\mathrm{II}}$ technique, Ankom filter bags (F57, $5.0 \mathrm{~cm} \times 5.5 \mathrm{~cm}$ ), placed in jars, and incubated for $48 \mathrm{~h}$ at $39^{\circ} \mathrm{C}$ in a buffer-inoculum solution using techniques similar to those described in detail by Vogel et al. [16] and Holden [17]. Buffer solution (1600 mL) and rumen inoculum $(400 \mathrm{~mL})$ were added to each jar, the jars purged with $\mathrm{CO}_{2}$. After incubation, the buffer-inoculum was drained from the jars and the filter bags were gently squeezed against the sides of the jar to remove the gas trapped in the inflated bags. The bags were rinsed in jars with three changes of warm tap water [17] and then removed and boiled in a neutral detergent solution [18] for $80 \mathrm{~min}$ using an Ankom200 fiber analyzer (ANKOM Technology Corporation, Fairport, NY, USA).

Filter bags were removed from jars and soaked in acetone for $5 \mathrm{~min}$, air-dried, then stored for at least $12 \mathrm{~h}$ in a $100^{\circ} \mathrm{C}$ oven, cooled in a desiccator, and weighed.

\subsection{Preparation of the Rumen Inoculum}

Ruminal inoculum was obtained from two rumen cannulated rams consuming a diet containing $120 \mathrm{~g} / \mathrm{kg} \mathrm{CP,} 560 \mathrm{~g} / \mathrm{kg}$ NDF, dry matter basis. Ruminal contents (1 L per ram) were obtained approximately $30 \mathrm{~min}$ after feeding and placed in a pre-warmed $\left(39^{\circ} \mathrm{C}\right)$ thermos.

Ruminal contents were brought into the laboratory, immediately strained through four layers of cheese cloth into a conical flack, and placed in a $39^{\circ} \mathrm{C}$ water bath.

\subsection{Calculation of Dry Matter and Neutral Detergent Fiber Digestibility}

Daisy ${ }^{\mathrm{II}}$ dry matter digestibility values (DMD) were calculated as follows:

$$
(1-([W 3-\{W 1 \times C 1\}] \times 1000) /(W 2 \times D M)),
$$

where $W 1$ is the filter bag weight, $W 2$ is the sample weight (as is), $W 3$ is the final weight (filter bag + residue) after in vitro or in situ and sequential treatment with NDF solution, $C 1$ is comparison of blank filter bag after and before digestion treatment weight, and DM is the dry matter content $(\mathrm{g} / \mathrm{kg})$ of samples.

Neutral detergent fiber digestibility (NDFD) was calculated using the following equation:

$$
(1-(([W 3-\{W 1 \times C 1\}] \times 1000) /(W 2 \times \mathrm{NDF}))),
$$

where $W 1$ is the filter bag weight, $W 2$ is the sample weight (as is), $W 3$ is the final weight (filter bag + residue) after in vitro or in situ and sequential treatment with NDF solution, $C 1$ is comparison of blank filter bag after and before diges- 
tion treatment weight, and sample NDF content ( $\mathrm{g} / \mathrm{kg}$ in as is sample).

\subsection{Chemical Analysis}

Following AOAC [19] procedures, samples were analyzed for $\mathrm{DM}\left(100^{\circ} \mathrm{C}\right.$ in air-forced oven for $24 \mathrm{~h}$; method 967.03), ash $\left(550^{\circ} \mathrm{C}\right.$ in ashing furnace for $6 \mathrm{~h}$; method 942), CP (Kjeldahl procedure), Additionally, samples were analyzed for neutral detergent fiber (NDF; with heat stable-amylase and sodium sulfite) and acid detergent fiber (ADF; ANKOM2000 fiber analyzer, ANKOM Technology Corporation, Fairport, NY, USA) according to Van Soest et al. [18].

\subsection{Statistical Analysis}

Differences among treatment means for significant dietary effect were detected using the LSD procedure of SAS [20]. Unless otherwise stated, significance was declared at $\mathrm{P}<0.05$.

\section{Results and Discussion}

The low quality roughage like wheat straw is insufficient to fill the energy requirement for ruminants despite their unique and highly efficient digestive system. Roughages must be properly processed or treated in some way to make them useful for production.

Results of this research showed that fungal treated wheat straw had more $(\mathrm{P}<$ 0.05) DM, ash and P contents compared to the untreated wheat straw.

Results showed that fungal treatment had significant effect on reduction $(\mathrm{P}<$ $0.05)$ of crude fiber, ADF and NDF and resulted in significant increase $(\mathrm{P}<0.05)$ in crude protein content of WS (Table 1). Treatment with fungi resulted in lower NDF by $7.5 \%$ (73.5\% vs. $66.0 \%)$, ADF by $6.6 \%$ (54.6\% vs, $48 \%$ ), ADL by $5.6 \%$ (14.6\% vs. 9.0\%) (Table 2). It is clear that the fungal treatment improved the nutritive value of WS through lowering the cell wall content fractions as indicated by NDF, ADF and ADL values. Similar results were reported by Fazaeli

Table 1. Chemical composition (\% of DM) of raw and fungal treated wheat straw.

\begin{tabular}{ccc}
\hline Parameter & UWS & TWS \\
\hline DM & $85.0^{\mathrm{b}}$ & $93.0^{\mathrm{a}}$ \\
Ash & $7.7^{\mathrm{b}}$ & $8.0^{\mathrm{a}}$ \\
CP & $4.2^{\mathrm{b}}$ & $5.5^{\mathrm{a}}$ \\
NDF & $73.5^{\mathrm{a}}$ & $66.0^{\mathrm{b}}$ \\
ADF & $54.6^{\mathrm{a}}$ & $48.0^{\mathrm{b}}$ \\
ADL & $14.6^{\mathrm{a}}$ & $9.0^{\mathrm{b}}$ \\
Ca & $0.44^{\mathrm{b}}$ & $0.60^{\mathrm{a}}$ \\
P & $0.12^{\mathrm{b}}$ & $0.20^{\mathrm{a}}$ \\
\hline
\end{tabular}

Values with different manuscript are significantly different at the $(\mathrm{P}<0.05)$ level. UWS: untreated wheat straw; TWS: treated wheat straw; NDF: neutral detergent fiber; ADF: acid detergent fiber; ADL: acid detergent lignin. 
Table 2. The Daisy ${ }^{\mathrm{II}}$ digestibility of raw and fungal treated wheat straw.

\begin{tabular}{ccc}
\hline & UWS & TWS \\
\hline DM & $0.51^{\mathrm{b}}$ & $0.57^{\mathrm{a}}$ \\
CP & $0.44^{\mathrm{b}}$ & $0.56^{\mathrm{a}}$ \\
NDF & $0.32^{\mathrm{b}}$ & $0.41^{\mathrm{a}}$ \\
ADF & $0.30^{\mathrm{b}}$ & $0.36^{\mathrm{a}}$ \\
GE & $0.51^{\mathrm{b}}$ & $0.57^{\mathrm{a}}$ \\
\hline
\end{tabular}

Values with different manuscript are significantly different at the $(\mathrm{P}<0.05)$ level. UWS: untreated wheat straw; TWS: treated wheat straw; NDF: neutral detergent fiber; ADF: acid detergent fiber; GE: gross energy.

et al. [21]. The higher ash content in treated WS may be due to the added minerals that associated with fungus used.

Shahzad et al. [10] showed that fungal treatment of WS increased CP and ash contents while cell wall contents were reduced. Similar effect of fugal treatment is on improving crude protein value in pea nut husk [22].

Arora and Sharma [23] observed that P. brevispora was found to be the best organism that significantly enhanced the in vitro feed digestibility. In another experiment, $50 \%$ increase in in vitro digestibility of WS was observed with $P$. floridensis. Sharma and Arora [24] and Okano et al. [25] observed an increased in vitro digestibility of Madake bamboo (Phyllostachys bambusoides) when treated with white rot Ceriporiopsis subvermispora for 10 weeks in solid state fermentation chamber.

The dry matter digestibility of fungal treated WS in our study was improved by $12 \%$ which was higher than that (7\% and $10 \%)$ reported by Shahzad et al. [10] and Fazaeli et al. [26], respectively. Similar trend was observed in higher digestibility of crude protein, NDF, ADF and gross energy where the digestibility of these parameters were $27 \%, 28 \%, 2 \%$ and $12 \%$, respectively (Table 2 ).

Zadrazil, [5] reported that in vitro digestibility of WS was increased by $25.5 \%$ when treated with some strains of Pleurotus, while other strains a $13.8 \%$ reduction in vitro digestibility.

Results from previous research concluded that improvement in in vitro dry matter digestibility was more than 7\% [21] [26] [27] [28]. In a study by Calzada et al. [9] the in vitro dry matter digestibility was improved up to $29.5 \%$ and a significant reduction in lignin content.

The variable effects fungal treatment of WS might be explained by the existence of many species and strains of fungi in nature and the differences in fungi activity with the raw WS.

\section{Conclusion}

Quality of WS can be improved by fungal treatment as shown in nutrient contents and digestibility. Several attempts should be applied in this regard to reach best results. It is important to specify the best fungus strain and the appropriate inoculation rate to achieve the objective of improving the straws nutritive value. 


\section{Acknowledgements}

We thank Palestinian Agricultural Academic Cooperation (PAAC) NICHE-PAA 233 Project Funded by NUFFIC_-The Netherlands.

\section{Conflicts of Interest}

The authors declare no conflicts of interest regarding the publication of this paper.

\section{References}

[1] Abo Omar, J. (2002) Effects of Feeding Different Levels of Sesame Oil Cake on Performance and Digestibility of Awassi Lambs. Small Ruminant Research, 46, 187-190. https://doi.org/10.1016/S0921-4488(02)00173-6

[2] Abo Omar, J. and Raed Daya, A.G. (2012) Effect of Different Forms of Olive Cake on the Performance of Awassi Lambs. Animal Feed Science and Technology, 171, 167-172.

[3] Abo Omar, J., Ahmad, Z., Maen, S., Bassam, A.S., Wael, Q. and Jehad, A. (2021) Effects of Guar (Cyamopsis tetragonoloba) Residues on the Performance and $\mathrm{Nu}$ trients Digestibility in Finishing Awassi Lambs. Open Journal of Animal Sciences, 11, 96-104. https://doi.org/10.4236/ojas.2021.111008

[4] Arora, J.K., Kakkar, V.K., Sukhvir, K. and Kaur, S. (1994) Bioconversion of Agro Residues for Food and Feed. Agricultural Reviews Karnal, 15, 3-4.

[5] Zadrazil, F. (1997) Changes in In Vitro Digestibility of Wheat Straw during Fungal Growth and after Harvest of Oyster Mushrooms (Pleurotus spp.) on Laboratory and Industrial Scale. Journal of Applied Animal Research, 11, 37-48. https://doi.org/10.1080/09712119.1997.9706159

[6] Yamakawa, M., Abe, H. and Okamoto, M. (1992) Effect of Incubation with Edible Mushroom, Pleurotus ostreatus, on Voluntary Intake and Digestibility of Rice Straw by Sheep. Animal Feed Science and Technology, 63, 133-138. https://doi.org/10.2508/chikusan.63.129

[7] Schanel, L., Herig, I., Dvorak, M. and Veznik, Z. (1966) Zpusob vyuziti mene vhodnych druhu slamy ke krmnym ucelum. Zlepsovaci navrh c. 13 (1,4 WVL Brno, CSSR).

[8] Zadražil, F. (1976) Ein Beitrag zur Strohzersetzung durch höhere Pilze (Basidiomyceten) und Nutzung für Ernährungs-und Düngezwecke. Sonderheft zur Z. Landwirtschaftliche Forschung, 31, 153-167.

[9] Calzada, J.F., Franco, L.F. and De Arriola, M.C. (1987) Acceptability, Body Weight Changes and Digestibility of Spent Wheat Straw after Harvesting of Pleurotus sajor-caju. Biological Wastes, 22, 303-309. https://doi.org/10.1016/0269-7483(87)90117-0

[10] Shahzad, F., Abdullah, M., Chaudhry, A.S., Bhatti, J.A., Jabbar, M.A., Ahmed, F., Mehmood, T., Asim, M., Ahmed, S., Kamran, Z., Irshad, I. and Tahir, M.N. (2016) Effects of Varying Levels of Fungal (Arachniotus sp.) Treated Wheat Straw as an Ingredient of Total Mixed Ration on Growth Performance and Nutrient Digestibility in Nili Ravi Buffalo Calves. Asian-Australasian Journal of Animal Sciences, 29, 359-364. https://doi.org/10.5713/ajas.15.0429

[11] Zadražil, F. (1985) Screening of Fungi for Lignin Decomposition and Conversion of Straw into Feed. Angewandte Botanik, 59, 433-452. 
[12] Zadražil, F. and Brunnert, H. (1980) The Influence of Ammonium Nitrate Supplementation on Degradation and in Vitro Digestibility of Straw Colonized by Higher Fungi. European Journal of Applied Microbiology and Biotechnology, 9, 37-44. https://doi.org/10.1007/BF00500000

[13] Zadražil, F. and Brunnert, H. (1982) Solid-State Fermentation of Lignocellulose Containing Plant Residues with Sporotrichum pulverulentum Nov. and Dichomitus squalens (Karst) Reid. European Journal of Applied Microbiology and Biotechnology, 16, 45-51. https://doi.org/10.1007/BF01008242

[14] Kamra, D.N. and Zadražil, F. (1987) Factors Affecting Micro-Biological Improvement of Lignocellulosics for Animal Feeding. In: Singh, K., Flegel, T.W. and Schiere, J.B., Eds., Biological, Chemical and Physical Treatment of Fibrous Crop Residues for Use as Animal Feed. Proceedings of International Workshop, 20-21 January 1987, New Delhi, India.

[15] Kamra, D.N. and Zadražil, F. (1988) Microbiological Improvement of Lignocellulosics in Animal Feed Production: A Review. In: Zadražil, F. and Reiniger P., Eds., Treatment of Lignocellulosics with White-Rot Fungi, Elsevier, Essex, 56-63.

[16] Vogel, K.P., Petersen, J.F., Masterson, S.D. and Toy, J.J. (1999) Evaluation of a Filter Bag System for NDF, ADF, and IVDMD Forage Analysis. Crop Science, 39, 276-279. https://doi.org/10.2135/cropsci1999.0011183X003900010042x

[17] Holden, L.A. (1999) Comparison of Methods of in Vitro Dry Matter Digestibility for Ten Feeds. Journal of Dairy Science, 82, 1791-1794. https://doi.org/10.3168/jds.S0022-0302(99)75409-3

[18] Van soest, P.J., Robertson, J.B. and Lewis, B.A. (1991) Methods of Dietary Fiber, Neutral Detergent Fiber and Non-Starch Polysaccharides in Relation to Animal Nutrition. Journal of Dairy Science, 74, 3583-3597. https://doi.org/10.3168/jds.S0022-0302(91)78551-2

[19] AOAC (1990) Official Methods of Analysis. 15th Edition, Association of Official Analytical Chemists, Washington DC.

[20] SAS Institute (2008) SAS User's Guide: Statistics. Version 6th Edition, SAS Institute Inc., Cary.

[21] Fazaeli, H., Mahmodzadeh, H., Jelan, Z.A., Rouzbenhan, Y., Liang, J.B. and Azizi, A. (2004) Utilization of Fungal Treated Wheat Straw in the Diet of Late Lactating Cow. Asian-Australasian Journal of Animal Sciences, 17, 467-472. https://doi.org/10.5713/ajas.2004.467

[22] Akinfemi, A. (2010) Bioconversion of Peanut Husk with White Rot Fungi: Pleurotus ostreatus and Pleurotus pulmonarius. Livestock Research for Rural Development, 22, 1-11.

[23] Arora, D.S. and Sharma, R.K. (2009) Comparative Ligninolytic Potential of Phlebia Species and Their Role in Improvement of In Vitro Digestibility of Wheat Straw. Journal of Animal and Feed Sciences, 18, 151-161. https://doi.org/10.22358/jafs/66379/2009

[24] Sharma, R.K. and Arora, D.S. (2010) Production of Lignocellulolytic Enzymes and Enhancement of in Vitro Digestibility during Solid State Fermentation of Wheat Straw by Phlebia floridensis. Bioresource Technology, 101, 9248-9253. https://doi.org/10.1016/j.biortech.2010.07.042

[25] Okano, K., Ohkoshi, N., Nishiyama, A., Usagawa, T. and Kitagawa, M. (2009) Improving the Nutritive Value of Madake Bamboo, Phyllostachys bambusoides, for Ruminants by Culturing with the White-Rot Fungus Ceriporiopsis subvermispora. Animal Feed Science and Technology, 152, 278-285. 
https://doi.org/10.1016/j.anifeedsci.2009.04.021

[26] Fazaeli, H., Jelan, Z.A., Mahmodzadeh, H., Liang, J.B., Azizi, A. and Osman, A. (2002) Effect of Fungal Treated Wheat Straw on the Diet of Lactating Cows. Asian-Australasian Journal of Animal Sciences, 15, 1573-1578.

https://doi.org/10.5713/ajas.2002.1573

[27] Jalc, D., Nerund, F. and Siroka, P. (1998) The Effectiveness of Biological Treatment on Wheat Straw by White-Rot Fungi. Folia Microbiologica, 43, 687-689. https://doi.org/10.1007/BF02816391

[28] Moyson, E. and Verachtert, H. (1991) Growth of Higher Fungi on Wheat Straw and Their Impact on the Digestibility of the Substrate. Applied Microbiology and Biotechnology, 36, 421-424. https://doi.org/10.1007/BF00208168 